Marquette University

e-Publications@Marquette

6-2009

\title{
Linking Conformation Change to Hemoglobin Activation Via Chain-Selective Time-resolved Resonance Raman Spectroscopy on Protoheme/Mesoheme Hybrids
}

\author{
Gurusamy Balakrishnan \\ University of Washington - Seattle Campus \\ Mohammed Ibrahim \\ University of Washington - Seattle Campus \\ Piotr J. Mak \\ Marquette University, piotr.mak@marquette.edu \\ Jessica Hata \\ Marquette University \\ James R. Kincaid \\ Marquette University, james.kincaid@marquette.edu
}

See next page for additional authors

Follow this and additional works at: https://epublications.marquette.edu/chem_fac

Part of the Chemistry Commons

\section{Recommended Citation}

Balakrishnan, Gurusamy; Ibrahim, Mohammed; Mak, Piotr J.; Hata, Jessica; Kincaid, James R.; and Spiro, Thomas G., "Linking Conformation Change to Hemoglobin Activation Via Chain-Selective Time-resolved Resonance Raman Spectroscopy on Protoheme/Mesoheme Hybrids" (2009). Chemistry Faculty Research and Publications. 398.

https://epublications.marquette.edu/chem_fac/398 
Authors

Gurusamy Balakrishnan, Mohammed Ibrahim, Piotr J. Mak, Jessica Hata, James R. Kincaid, and Thomas G. Spiro

This article is available at e-Publications@Marquette: https://epublications.marquette.edu/chem_fac/398 


\title{
Linking Conformation Change to Hemoglobin Activation Via Chain- Selective Time-resolved Resonance Raman Spectroscopy on Protoheme/Mesoheme Hybrids
}

\author{
Gurusamy Balakrishnan \\ Department of Chemistry, University of Washington \\ Seattle, WA \\ Mohammed Ibrahim \\ Department of Chemistry, University of Washington \\ Seattle, WA \\ Piotr J. Mak \\ Department of Chemistry, Marquette University \\ Milwaukee, WI \\ Jessica Hata \\ Department of Chemistry, Marquette University \\ Milwaukee, WI
}


NOT THE PUBLISHED VERSION; this is the author's final, peer-reviewed manuscript. The published version may be accessed by following the link in the citation at the bottom of the page.

\author{
James R. Kincaid \\ Department of Chemistry, Marquette University \\ Milwaukee, WI \\ Thomas G. Spiro \\ Department of Chemistry, University of Washington \\ Seattle, WA
}

\begin{abstract}
:
Time-resolved Resonance Raman spectra are reported for $\mathrm{Hb}$ tetramers, in which the aand $\beta$ chains are selectively substituted with mesoheme. The Soret absorbtion band shift in meso- relative to proto-heme permits chainselective excitation of heme RR spectra. The evolution of these spectra following $\mathrm{HbCO}$ photolysis show that geminate recombination rates and yields are the same for the two chains, consistent with recent results on ${ }^{15} \mathrm{~N}$-heme isotopomer hybrids. The spectra also reveal systematic shifts in the deoxyheme $\mathrm{V}_{4}$ and $\mathrm{V}_{\mathrm{Fe}}$-His) RR bands, which are anti-correlated. These shifts are resolved for the successive intermediates in the protein structure, which have previously been determined from time-resolved UVRR spectra. Both chains show Fe-His bond compression in the immediate photoproduct, which relaxes during the formation of the first intermediate, $R_{\text {deoxy }}(0.07 \mu \mathrm{s})$, in which the proximal F-helix is proposed to move away from the heme. Subsequently, the Fe-His bond weakens, more so for the a than the $\beta$ chains. The weakening is gradual for the $\beta$ chains, but abrupt for the a chains, coinciding with completion of the R-T quaternary transition, at $20 \mu \mathrm{s}$. Since the transition from fast- to slow-rebinding $\mathrm{Hb}$ also occurs at $20 \mu \mathrm{s}$, the drop in the a chain $\mathrm{VFe}-\mathrm{His}$ supports the localization of ligation restraint to tension in the Fe-His bond, at least in the a-chains. The mechanism is more complex in the $\beta$ chains.
\end{abstract}

Keywords: Protoheme/mesoheme, hybrid hemoglobin, resonance Raman, geminate recombination, allostery.

\title{
Introduction
}

Understanding the connection between heme ligation and protein conformation change has long been a major aim of research on hemoglobin $(\mathrm{Hb})$, the paradigmatic allosteric protein. In Perutz' original stereochemical mechanism (1), this connection is provided by

Journal of Biological Inorganic Chemistry, Vol. 14, No. 5 (June 2009): pg. 741-750. DOI. This article is (C) Springer and permission has been granted for this version to appear in e-Publications@Marquette. Springer does not grant permission for this article to be further copied/distributed or hosted elsewhere without the express permission from Springer. 
constraint on the heme Fe, which lies below the heme plane in fivecoordinate high-spin deoxy heme, but must approach the plane in order to bind an exogenous ligand. Constraint on this motion by the protein lowers the ligand affinity, while overcoming the constraint induces changes in the protein structure and alters contacts at the subunit interfaces, thereby destabilizing the T quaternary structure, relative to the $\mathrm{R}$ structure that is characteristic of ligated $\mathrm{Hb}(2-4)$.

This constraint is transduced by the bond connecting the Fe to the proximal histidine ligand. The stretching vibration of this bond produces a detectable resonance Raman signal in the deoxy form of $\mathrm{Hb}$, whose frequency is distinctively lower than in deoxy-myoglobin or in relaxed forms of $\mathrm{Hb}, \sim 216$ vs $\sim 222 \mathrm{~cm}^{-1}$ (5-10). This evidence for $\mathrm{Fe}-\mathrm{His}$ bond weakening is the most direct sign of molecular tension in the $\mathrm{T}$ state. The $\mathrm{V}_{\mathrm{Fe}-\mathrm{His}} \mathrm{RR}$ band therefore provides a useful monitor for the heme-protein dynamics (11-15).

However, this form of tension is more pronounced in the a than the $\beta$ chains. A variety of evidence points to selective weakening of the Fe-His bond in the a-chains of dexyHb $(6,9,16)$. RR studies on hybrid $\mathrm{Hb}^{\prime}$ 's have indicated that the band is at $\sim 218 \mathrm{~cm}^{-1}$ in the $\beta$ chains but at $\sim 207 \mathrm{~cm}^{-1}$ in the a chains. For native $\mathrm{Hb}$, the presence of overlapping contributions from the two chains has complicated the interpretation of time-resolved RR studies, in which the $\mathrm{Fe}_{\mathrm{Fe}-\mathrm{His}} \mathrm{RR}$ band is monitored during evolution of the protein from the $\mathrm{R}$ to the $\mathrm{T}$ state, following $\mathrm{HbCO}$ photolysis (11-15). In the present work, we remove this interference by employing chain-selective substitution of mesoheme, in which the vinyl substituents of protoheme are replaced with ethyl groups. This replacement shifts the Soret absorption band of the heme, thereby allowing RR selectivity via appropriate choice of laser wavelength $(16,17)$. We show that the a chains are indeed the locus of most of the $\mathrm{V}_{\mathrm{Fe}-\mathrm{His}}$ perturbation, and we link the successive steps in its evolution to tertiary and quaternary changes in the protein that have previously been established by UVRR spectroscopy $(13,18,19)$.

\section{Materials and Methods}

\section{Protein Preparation}

The human hemoglobin ( $\mathrm{HbA}$ ) was isolated from red blood cells according to the previously published procedures $(20,21)$ and stored as the $\mathrm{CO}$ adduct. The apohemoglobin (apoHb) was obtained using acid-acetone method $(22,23)$. The meso-heme substituted hemoglobin (mesoHb) was obtained by reconstitution of apoHb with $\mathrm{Fe}$ (III)

Journal of Biological Inorganic Chemistry, Vol. 14, No. 5 (June 2009): pg. 741-750. DOI. This article is @ Springer and permission has been granted for this version to appear in e-Publications@Marquette. Springer does not grant permission for this article to be further copied/distributed or hosted elsewhere without the express permission from Springer. 
mesoporphyrin IX chloride (meso-heme, Frontier Scientific, Logan, Utah $)(16,22,23)$. The $\mathrm{HbA}$ and reconstituted mesoHb were separated into subunits using p-(chloromercuri)benzoate (PMB, Sigma-Aldrich, Milwaukee, WI $(16,24-26)$. The isolated subunits were regenerated by 2-mercaptoethanol (BME, Sigma-Aldrich, Milwaukee, WI) and purified according to well established procedures (16, 24-26). The purified ferrous $\mathrm{CO}$ subunits were equilibrated with $100 \mathrm{mM}$ phosphate buffer 7.4 before hybrid formation. The $\left(a_{\text {proto }} \beta_{\text {meso }}\right)_{2}$ hybrids were prepared by combining 1.2 molar excess of $\beta_{\text {meso }}$ subunits with $a_{\text {proto }}$ subunits, followed by overnight incubation at $4^{\circ} \mathrm{C}$ to ensure tetramer formation $(16,27,28)$. The $\left(a_{\text {meso }} \beta_{\text {proto }}\right)_{2}$ hybrids were prepared is similar way using corresponding appropriate subunits(16, 27, 28). The excess of $\beta$ subunits was removed using column chromatography(CM52) as described previously $(16,17,27,28)$. In order to further ensure that the samples are in the pure ferrous $\mathrm{CO}$ state, sodium dithionite was added under CO atmosphere. Excess dithionite was removed by passing the fully reduced $\mathrm{CO}$ samples through Bio-Gel P-6 column equilibrated with a CO-saturated $50 \mathrm{mM}$ phosphate buffer $\mathrm{pH}$ 7.4. Purity of the hybrids was confirmed by UVvis spectroscopy (29) (Hewlett-Packard Model 8452 Diode Array Spectrophotometer). The concentrations of all samples used for RR measurements were $\sim 0.4 \mathrm{mM}$ in heme in CO-saturated $50 \mathrm{mM}$ phosphate buffer, $\mathrm{pH} 7.4$.

About $350 \mu$ of sample solution was contained in a CO saturated septum sealed $5 \mathrm{~mm}$ glass NMR tube. The solution was stirred via a stationary stirrer bar/magnet combination through spinning of the sample tube. The diameters of the pump and probe laser spots at the samples were estimated to be $\sim 80$ and $60 \mu \mathrm{m}$ respectively and the diameter of the NMR tube was $5 \mathrm{~mm}$. To avoid spatial overlap mismatch between pump and probe laser spots, and to ensure that successive pulses excited a new sample volume, the spinning speed of the NMR tube (monitored on-line by a tachometer (08210, Cole Parmer)) was optimized to 800 rpm for 200 ns to 3 us time delays, $500 \mathrm{rpm}$ for 6 to 50 us delays, and $300 \mathrm{rpm}$ for longer delay times. The shape of the $\mathrm{CO}$ recombination profiles were compared with previous studies to verify the reliability of the spinning speed used in the present experiment. Sample integrity was checked by the reproducibility of Raman and absorption spectra.

Solutions of deoxy-HbA (and deoxy-mesoHb, deoxyproto/meso-hybrids) $(0.4 \mathrm{mM}$ in heme) were generated in $50 \mathrm{mM}$ phosphate buffer at $\mathrm{pH} 7.4$ by irradiating the deoxygenated protein solutions with visible light at $4{ }^{\circ} \mathrm{C}$ under flowing ultra-pure $\mathrm{N}_{2}$. About

Journal of Biological Inorganic Chemistry, Vol. 14, No. 5 (June 2009): pg. 741-750. DOI. This article is @ Springer and permission has been granted for this version to appear in e-Publications@Marquette. Springer does not grant permission for this article to be further copied/distributed or hosted elsewhere without the express permission from Springer. 
NOT THE PUBLISHED VERSION; this is the author's final, peer-reviewed manuscript. The published version may be accessed by following the link in the citation at the bottom of the page.

$0.4 \mathrm{ml}$ of solution was transferred to an septum sealed NMR tube under excess $\mathrm{N}_{2}$ pressure.

\section{Resonance Raman Spectroscopy}

The time-resolved resonance Raman $\left(\mathrm{TR}^{3}\right)$ spectroscopic setup has been described elsewhere $(30,31)$. Briefly, photolysis pulses at $419 \mathrm{~nm}$ (20 ns, 60 $\mathrm{J} /$ pulse, $1 \mathrm{kHz}$ ) were generated by frequency doubling the output of a Ti-Sapphire laser (Photonics International Industries), which was pumped (527 nm, 10 mJ/pulse, $70 \mathrm{~ns}, 1 \mathrm{kHz}$ ) by an intracavity frequency-doubled Nd-YLF laser (GM30, Photonics International Inc). Probe pulses ( $20 \mathrm{~ns}, 1 \mathrm{kHz})$ at $440 \mathrm{~nm}(0.5$ $\mu \mathrm{J} /$ pulse) were obtained by frequency doubling a second Ti-Sapphire laser(Photonics International Industries). Scattered light was collected at $135^{\circ}$ with a camera lens ( $f$ \# 1.2) and focused using a f-matched singlet lens at the entrance slit of the $0.8 \mathrm{~m}$ spectrograph (Spex 1401) equipped with a holographic grating (1800 groove $\mathrm{mm}^{-1}$ ) and intensified CCD (PI/MAX, Princeton Instruments). A time-delay signal generator (DG535, Stanford Research) was used to control the delay time between pump and probe pulses and synchronize the Raman scattered signals from the probe pulse with the gate of the detector. Interfering signals from the pump laser were eliminated by electronically gating the detector. The time-resolution of the current set up is $40 \mathrm{~ns}$. The probe pulse wavelength, $440 \mathrm{~nm}$, was selected to provide selective resonance enhancement of protoheme in deoxy- $\mathrm{HbA}$ and deoxy-proto/meso-hybrids. Static RR spectra of deoxy Hb samples were obtained using the same experimental set-up as above.

The RR spectral data were processed with Grams/AI (7.0) software (Thermo Galactic). The bound $\mathrm{CO}$ fraction was determined at each delay, by deconvoluting the peaks and dividing their heights by those obtained from a probe-only spectrum (in order to compensate for the measurable photolysis induced by the probe pulse). The component spectra of photoproducts were obtained using UVRR derived time constants by means of linear least squares in Matlab(18).

\section{Results}

Substitution of the proto-heme vinyl substituents by ethyl groups produces a $\sim 10 \mathrm{~nm}$ blueshift of the heme Soret absorption band $(32,33)$, as illustrated in Fig. 1. The broad deoxyHb Soret bands are readily deconvoluted into separate contributions from the protoand meso-heme chromophores, and an additional short-wavelength contribution from vibronic side-bands. Interestingly, the heme

Journal of Biological Inorganic Chemistry, Vol. 14, No. 5 (June 2009): pg. 741-750. DOI. This article is (C) Springer and permission has been granted for this version to appear in e-Publications@Marquette. Springer does not grant permission for this article to be further copied/distributed or hosted elsewhere without the express permission from Springer 
NOT THE PUBLISHED VERSION; this is the author's final, peer-reviewed manuscript. The published version may be accessed by following the link in the citation at the bottom of the page.

absorptivity in the a chains is higher than that of the $\beta$ chains as previously noted $(32,33)$. This difference accounts for the greater RR enhancement seen for a than for $\beta$ chains in our recent study of ${ }^{15} \mathrm{~N}$ heme isotopic hybrids of $\mathrm{Hb}(34)$.

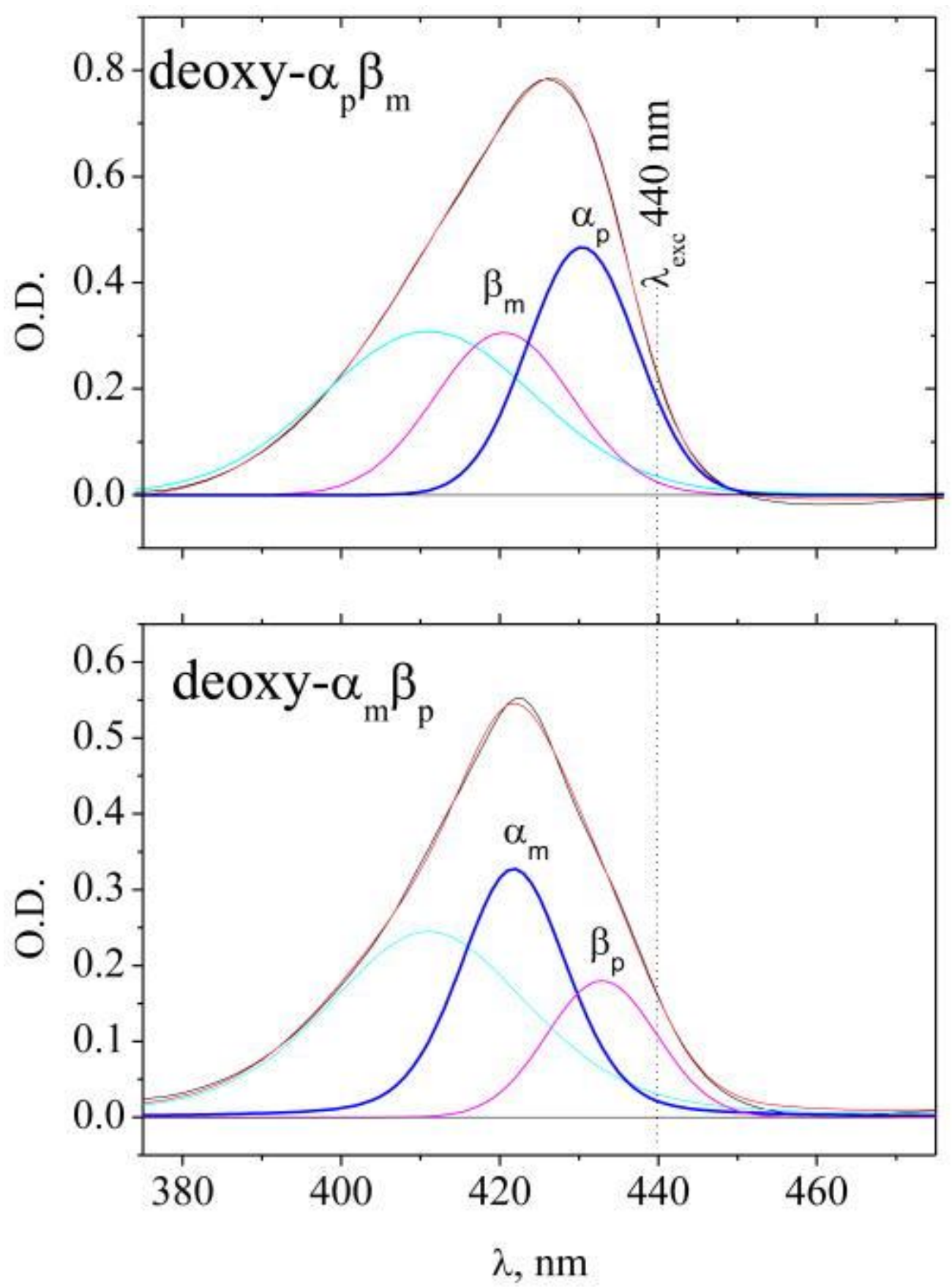

Figure 1 Soret absorption envelops for the meso-proto hybrid Hb's, showing the

Journal of Biological Inorganic Chemistry, Vol. 14, No. 5 (June 2009): pg. 741-750. DOI. This article is @ Springer and permission has been granted for this version to appear in e-Publications@Marquette. Springer does not grant permission for this article to be further copied/distributed or hosted elsewhere without the express permission from Springer. 
proximity of the $440 \mathrm{~nm}$ Raman laser wavelength to the deconvoluted proto-heme band.

Because of the $10 \mathrm{~nm}$ separation between the proto- and mesoheme contributions, excitation on the long wavelength side of the absorption band $(440 \mathrm{~nm})$ provides selective enhancement of the proto-heme RR spectra (16). Figure 2 shows that the RR spectrum of $\mathrm{Hb}$ with meso-heme in both chains can still be recorded at this wavelength (bottom spectrum), but the enhancement is $\sim 3$ times lower than for native $\mathrm{Hb}$ (top spectrum). Saturation of the vinyl double bonds also eliminates the characteristic vinyl $\mathrm{C}=\mathrm{C}$ stretching mode, at $1622 \mathrm{~cm}^{-1}$ and shifts the porphyrin skeletal modes to varying extents (35). Particularly noticeable is the $17 \mathrm{~cm}^{-1}$ upshift of the $v_{2}$ band, to $1585 \mathrm{~cm}^{-1}$. Proto-heme has only a weak $\mathrm{v}_{4}$ band at $1528 \mathrm{~cm}^{-1}$ with equal intensity in the RR spectrum of native $\mathrm{Hb}$ and the two hybrids, confirming that contribution of meso-heme to the proto-hemedominated $440 \mathrm{~nm}$ RR spectra is small. Other differences are seen in the low-frequency region, where the $300 \mathrm{~cm}^{-1}$ band appears to shift up $27 \mathrm{~cm}^{-1}$. This band has been identified $(16,17,35)$ as a porphyrin out-of-plane mode, $Y_{7}$, but it has a substantial contribution from the vinyl substituents(36-38), likely accounting for the up-shift upon the removal of vinyl conjugation. It is noted that the relatively strong $Y_{7}$ mode of the mesoheme is not seen in the spectra of the hybrid acquired with $440 \mathrm{~nm}$ excitation, ensuring that the bands seen in the hybrids are exclusively from the proto-heme-bearing chains. Consistent with previous hybrid data $(9,16,39)$, the $v_{\mathrm{Fe}-H i s}$ band is found at $218 \mathrm{~cm}^{-1}$ for the $\beta$ chains, while the a chain envelope has 203 and $214 \mathrm{~cm}^{-1}$ contributions. 


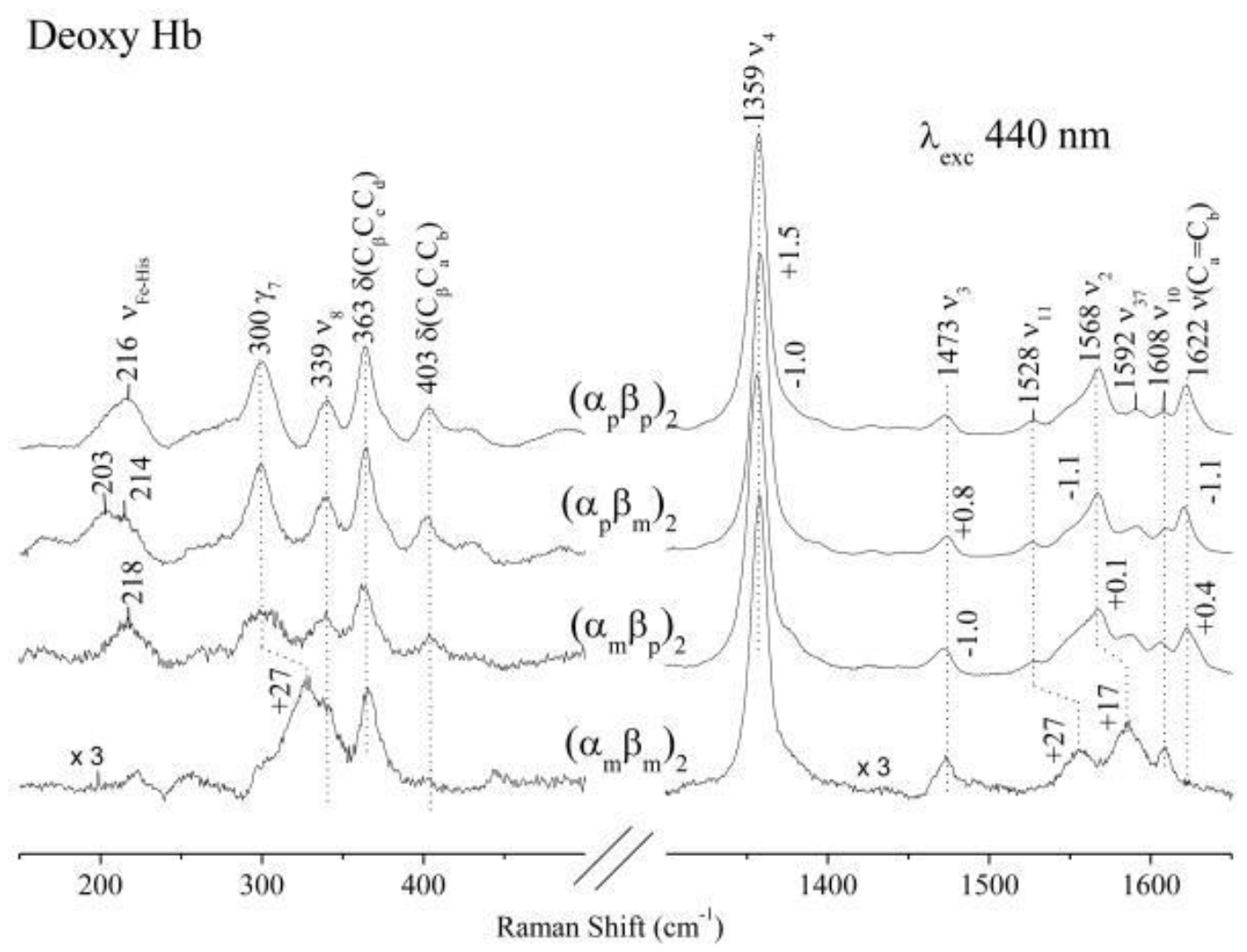

Figure 2 The $440 \mathrm{~nm}$ - excited RR spectra of native (top) and meso-Hb (bottom), and of the two meso-proto hybrids. Band assignments and frequency shifts are indicated.

Figure 2 also reveals RR differences in the high-frequency region between the $a$ and $\beta$ chains in deoxyHb. The a chain frequencies are 2.5 and $1.8 \mathrm{~cm}^{-1}$ higher than the $\beta$ chain frequencies for $v_{4}$ and $v_{3}$, but 1.2 and $1.5 \mathrm{~cm}^{-1}$ lower for $\mathrm{v}_{2}$ and $\mathrm{v}_{\mathrm{C}=\mathrm{c}}$. The $\mathrm{v}_{4}$ elevation for the $\mathrm{a}$ chains was previously noted in ${ }^{15} \mathrm{~N}$-heme isotopic hybrids (34), and is attributed to the electronic effects associated with strain in the Fe-His bond (see below) since a negative correlation has been established between the deoxy-heme $\mathrm{v}_{4}$ and $\mathrm{v}_{\mathrm{Fe} \text {-His }}$ frequencies (10). The other heme mode shifts are likely due to the same effects.

Fig. 3 shows the time evolution of $\mathrm{v}_{4}$, following $\mathrm{HbCO}$ photolysis with a saturating pump pulse. The deoxy-heme $v_{4}$ frequencies are the same for the two chains at the earliest time, and evolve to higher values for the $a$, but not for $\beta$ chains. The $1376 \mathrm{~cm}^{-1}$ band from COheme reflects geminate recombination at early times, and secondorder recombination of $\mathrm{CO}$ from solution at later times. The deoxyand CO-heme contributions are readily deconvoluted, and the peak heights, corrected for the small extent of re-photolysis generated by 
the probe pulse (bottom spectra), can be used to construct rebinding yield curves (Fig. 4), as described previously (18). The geminate and second-order rebinding phases are well separated in time, and the plateau between them gives an accurate measure of the geminate yield, which is $42 \pm 2 \%$ for native $\mathrm{Hb}$ and for both hybrids. Fully meso-heme-substituted $\mathrm{Hb}$ was included as a control, and gave the same geminate yield, confirming that the substitution has no effect on rebinding. The absence of any detectable difference between the $a$ and $\beta$ chains confirms our recent result using ${ }^{15} \mathrm{~N}$ heme substitution (34).

$$
\lambda_{\mathrm{exc}} 440 \mathrm{~nm}
$$
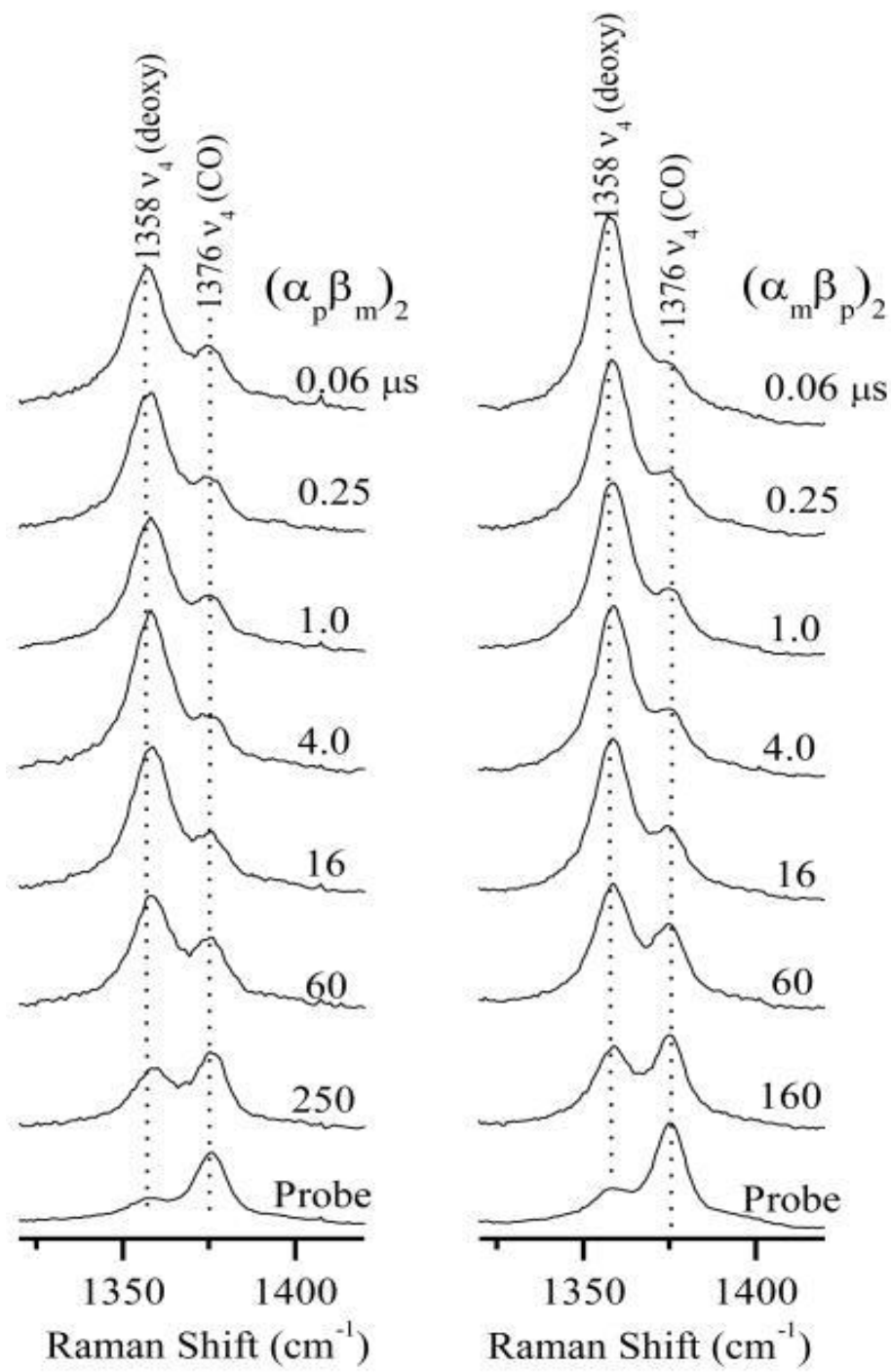

Figure 3 The RR spectra of hybrid $\mathrm{Hb}^{\prime} \mathrm{s}$ in the $\mathrm{v}_{4}$ region at the indicated delays following $\mathrm{HbCO}$ photolysis. The probe-only spectrum (bottom) reveals partial photolysis by the probe pulse. 
NOT THE PUBLISHED VERSION; this is the author's final, peer-reviewed manuscript. The published version may be accessed by following the link in the citation at the bottom of the page.
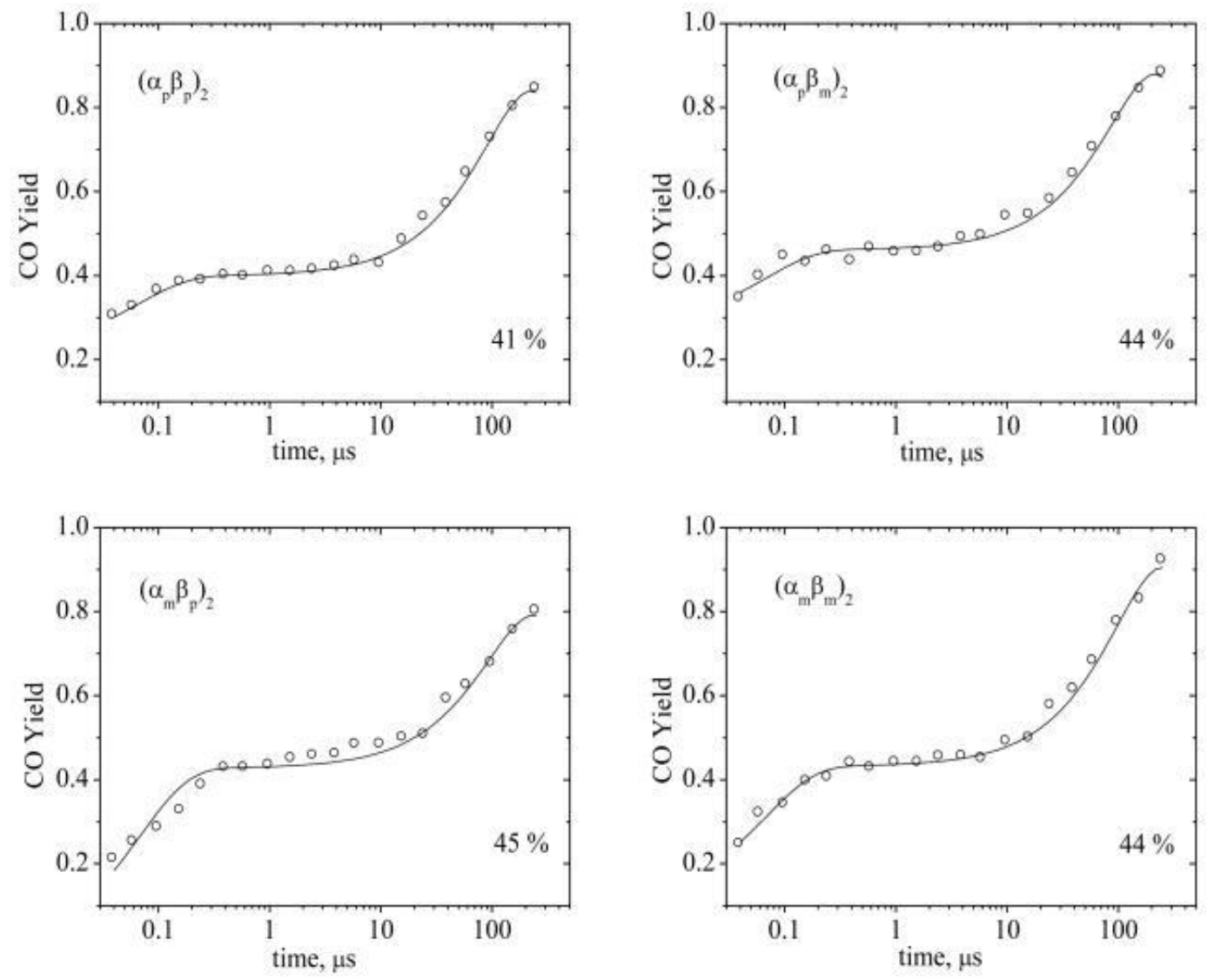

Figure 4 The $\mathrm{CO}$ recombination progress curves for the indicated $\mathrm{Hb}$ forms, calculated via the $\mathrm{v}_{4}$ intensities.

Fig. 5 shows the time evolution of low-frequency RR difference spectra [(pump+probe) minus (probe-only)] for the two hybrid $\mathrm{Hb}^{\prime} \mathrm{s}$. The $\mathrm{V}_{\mathrm{Fe}-\mathrm{His}}$ band is seen only for deoxy-heme. Its observation in the probe-only spectra is due to partial photolysis from the probe pulse. As previously noted (11-15), this vibration has an elevated frequency, $\sim 228 \mathrm{~cm}^{-1}$, immediately after photolysis, which then decreases with time. The magnitude of this evolving frequency shift is more pronounced for the a than the $\beta$ chain (vide infra). 


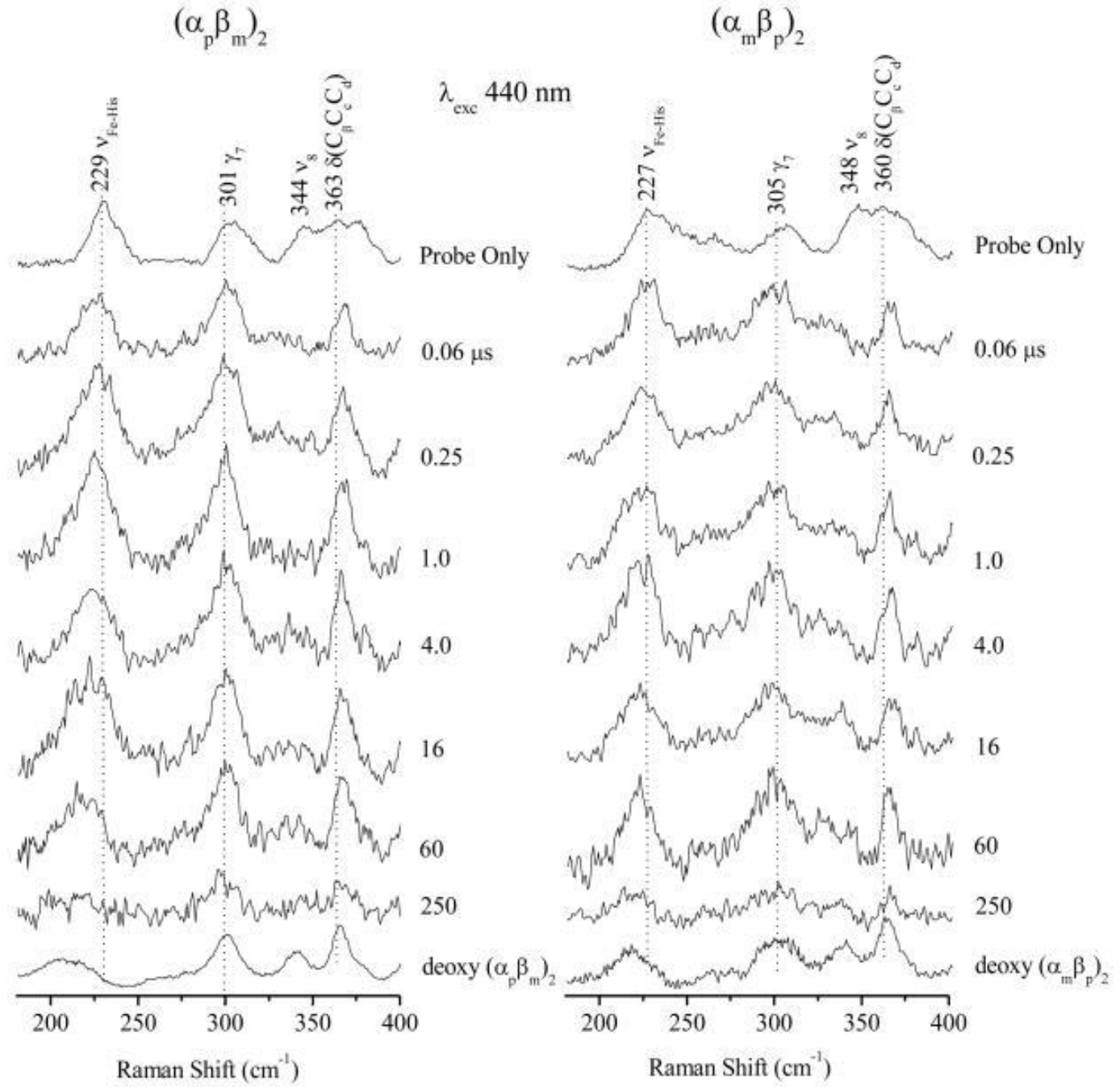

Figure 5 Pump/probe minus probe only RR spectra at the indicated time delays. The $\sim 228 \mathrm{~cm}^{-1} V_{\mathrm{Fe}-H i s}$ bands in the probe only spectra (top) are due to partial photolysis. Static deoxy Hb spectra are compared (bottom).

The spectra were analyzed with the aid of a kinetic model derived from time-resolved UVRR studies (18); the exact procedure used to extract the spectra of the various kinetic intermediates from the set of raw spectra obtained here at different times is described in detail in the cited reference. These spectra are displayed in Fig. 6 and and7,7, and are discussed below. 


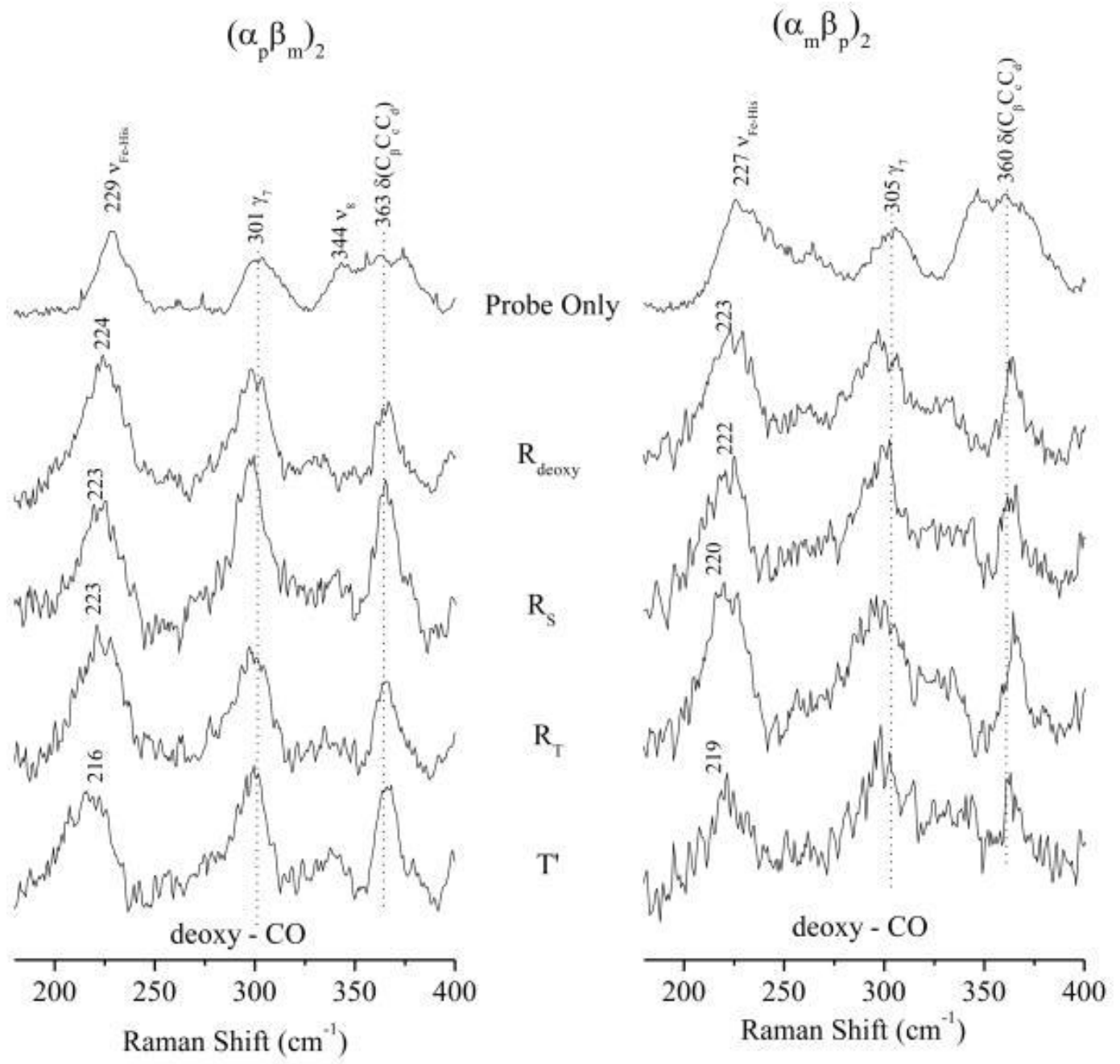

Figure 6 Computed RR spectra in the low frequency region after HbCO photolysis, as determined from time-resolved UVRR analysis(18).

Journal of Biological Inorganic Chemistry, Vol. 14, No. 5 (June 2009): pg. 741-750. DOI. This article is (C) Springer and permission has been granted for this version to appear in e-Publications@Marquette. Springer does not grant permission for this article to be further copied/distributed or hosted elsewhere without the express permission from Springer. 
NOT THE PUBLISHED VERSION; this is the author's final, peer-reviewed manuscript. The published version may be accessed by following the link in the citation at the bottom of the page.

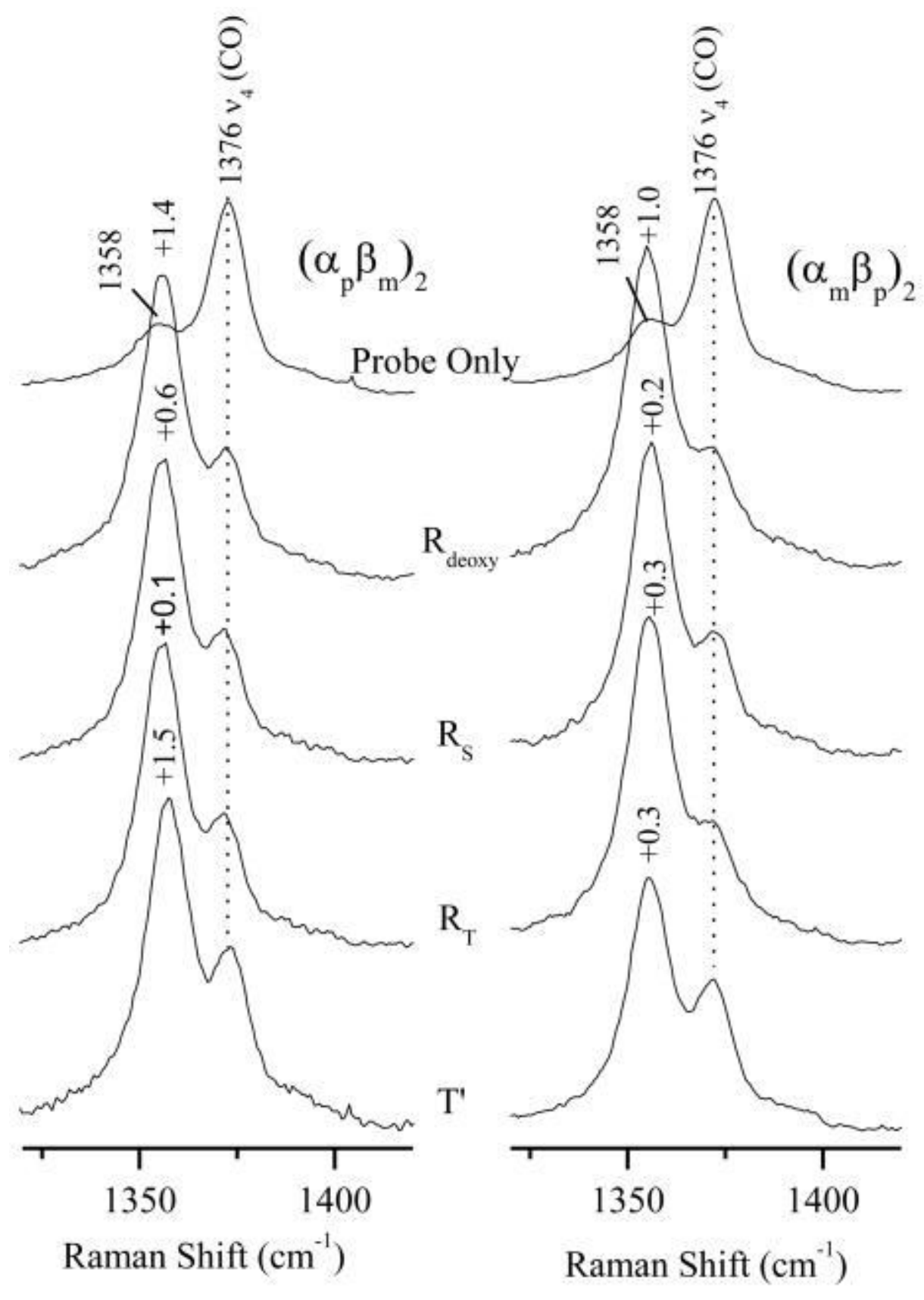

Figure 7 Computed RR spectra in the $\mathrm{v}_{4}$ region after $\mathrm{HbCO}$ photolysis, as determined from time-resolved UVRR analysis(18).

\section{Discussion}

As demonstrated previously, the substitution of meso-heme for the native proto-heme in $\mathrm{Hb}$ allows for chain-selective recording of heme RR spectra. In the present study, we used excitation at $440 \mathrm{~nm}$,

Journal of Biological Inorganic Chemistry, Vol. 14, No. 5 (June 2009): pg. 741-750. DOI. This article is @ Springer and permission has been granted for this version to appear in e-Publications@Marquette. Springer does not grant permission for this article to be further copied/distributed or hosted elsewhere without the express permission from Springer. 
where RR scattering is strong from proto-heme, but weak from mesoheme (Figure 1), in order to selectively monitor the protoheme vibrations in the proto/meso hybrid Hb's.

Although the meso/proto-heme substitution in $\mathrm{Hb}$ does have modest functional effects (40-43) (higher affinity, lower cooperativity) the present results show that geminate recombination is unaffected, and is equally probable in the $a$ and $\beta$ chains, confirming the result of our recent study using ${ }^{15} \mathrm{~N}$-heme isotopic hybrids (34). We discussed there the possibility that this equivalence might reflect mechanical coupling within an a $\beta$ dimer, or might be coincidental, the result of convergent evolution toward a cooperative tetramer.

An important additional opportunity is presented by these proto/meso hybrids in that they also allow us to monitor the evolution of the Fe-His stretching vibration. It has long been known that its frequency is depressed in deoxyHb $(5-7,9-14,39)$, reflecting the molecular tension associated with the $\mathrm{T}$ state. Moreover the frequency lowering is greater for the a than the $\beta$ chains. This can be seen in the deoxyHb spectra in Fig. 2, showing the $a_{p}$ RR Fe-His band to consist of two components, 203 and $214 \mathrm{~cm}^{-1}$, confirming earlier observations with hybrids Hb's $(6,9,10,16)$. The $\beta_{p}$ heme has a single band at 218 $\mathrm{cm}^{-1}$, while native $\mathrm{Hb}$ has an asymmetric band, reflecting the sum of a and $\beta$ contributions. The source of the heterogeneity reflected in the two-component $a_{p} \operatorname{RR}$ band has yet to be determined $(6,9,10,16)$, but the greater weakening of the a chain $\mathrm{Fe}-\mathrm{His}$ bond is clear. Other manifestations of weaker Fe-His bonding in the deoxyHb a chains include a-selective severing of this bond at low $\mathrm{pH}$ or in the presence of allosteric effectors when NO is bound (due to the NO trans effect)(44,45), or when $\mathrm{Ni}(\mathrm{II})$ is substituted for $\mathrm{Fe}$ (II) (the $\mathrm{Ni}$ (II) axial bonding being weak)(46). Also, greater splitting of the Q absorption band is seen in high-resolution emission spectra when $\mathrm{Zn}$ (II) is substituted in the a than in the $\beta$ chains in $\mathrm{Hb}(47)$. The time-resolved RR spectra in Fig. 5 show that the Fe-His perturbation is also more extensive in the a chains than in the $\beta$ chains.

UVRR spectroscopy has previously been used to characterize the protein structure changes following $\mathrm{HbCO}$ photolysis $(13,18,19)$. The time-course of tryptophan and tyrosine mode intensities defined a set of transitions, associated with well-separated time constants of 0.07 , $0.75,2.9$ and $20 \mu \mathrm{s}$, prior to recombination with solution $\mathrm{CO}$ to reform $\mathrm{HbCO}$ (18). The kinetic model based on these transitions afforded a set of UVRR spectra for the kinetic intermediates, which permitted interpretation of the structural changes. The resulting model of the allosteric reaction coordinate is shown in Figure 8. Photolysis of ligated

Journal of Biological Inorganic Chemistry, Vol. 14, No. 5 (June 2009): pg. 741-750. DOI. This article is @ Springer and permission has been granted for this version to appear in e-Publications@Marquette. Springer does not grant permission for this article to be further copied/distributed or hosted elsewhere without the express permission from Springer. 
heme $(\mathrm{A})$ leaves $\mathrm{CO}$ in the distal pocket $(\mathrm{B})$ while the $\mathrm{Fe}-\mathrm{His}$ bond is compressed, as the Fe atom is driven out of the heme plane by its conversion to a high-spin state. It has long been known that the FeHis frequency is elevated in the immediate photoproduct of $\mathrm{HbCO}(11-$ $15)$. This can be seen in the probe-only RR spectra, shown in Fig. 6. The photoproducts generated by the probe pulse display Fe-His bands at $229\left(\mathrm{a}_{\mathrm{p}}\right)$ and $227\left(\beta_{\mathrm{p}}\right) \mathrm{cm}^{-1}$.

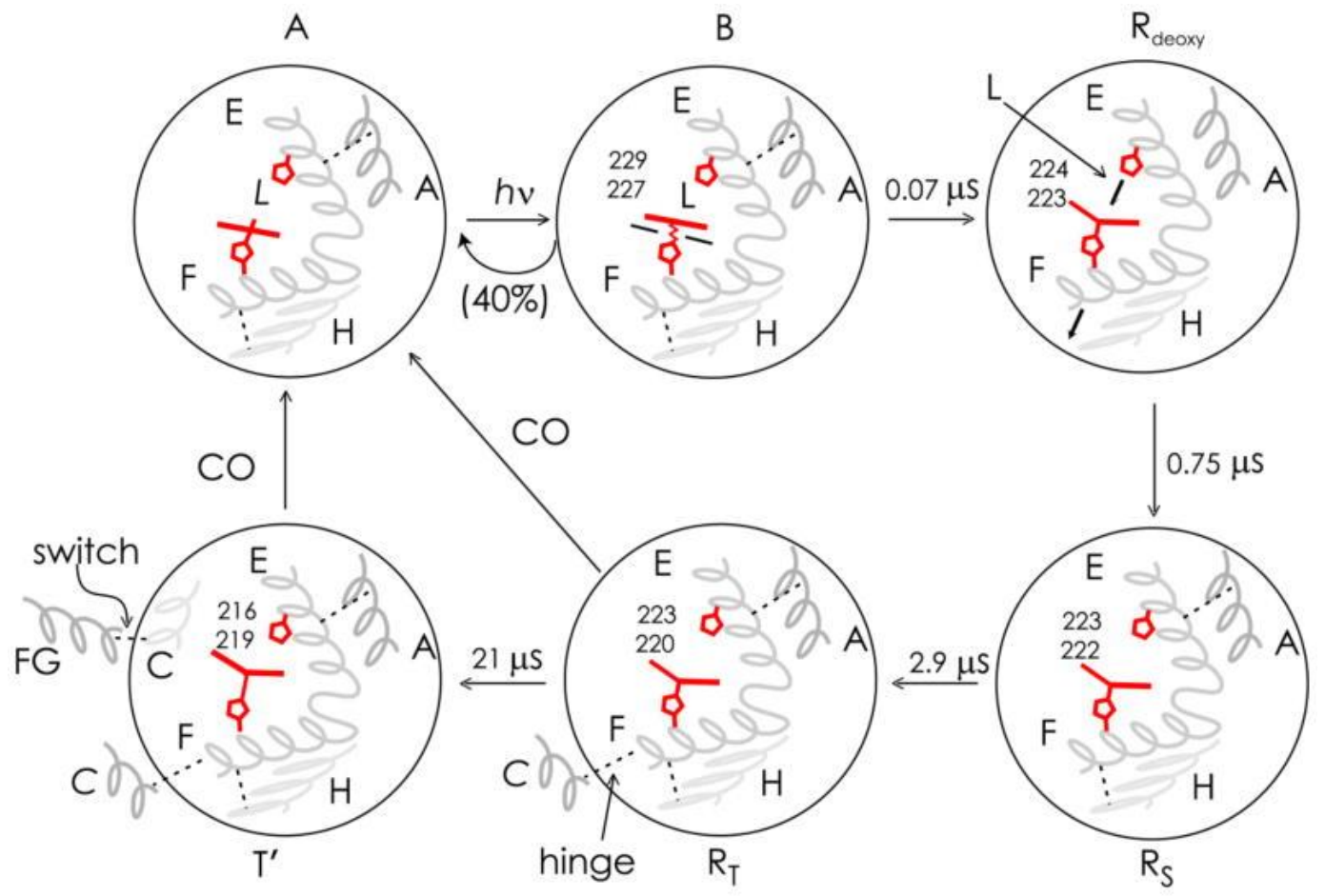

Figure 8 Allosteric model for the reaction path following $\mathrm{HbCO}$ photolysis showing the $v_{\mathrm{Fe} \text {-His }}$ values for the intermediates (upper number for a subunit, lower number for Bsubunit)[ see text for descriptions of the intermediates].

The first protein motion, at $0.07 \mu \mathrm{s}$, produces an intermediate called $R_{\text {deoxy, }}$, because its difference spectrum can be simulated by $\mathrm{Hb}$ constructs in which ligands are absent in one or more subunits but the quaternary structure remains $\mathrm{R}(48)$. This spectrum is characterized by large Trp and Tyr intensity losses, which have been shown to result from breaking of tertiary $\mathrm{H}$-bonds between the $\mathrm{E}$ and $\mathrm{A}$ helices (49, 50 ), and between the $\mathrm{F}$ and $\mathrm{H}$ helices (51) (Rdeoxy in Fig. 8). The $\mathrm{E}$ and $\mathrm{F}$ helices hold the heme like a clamshell, and the interhelical $\mathrm{H}$-bonds are proposed to break as a result of rotation of the clamshell. This rotation results from the proximal $\mathrm{F}$ helix moving away from the heme, impelled by the $\mathrm{Fe}-\mathrm{His}$ bond compression. The resulting relaxation of the $\mathrm{Fe}-\mathrm{His}$ bond can be seen in the visible RR difference spectra 
extracted for the $R_{\text {deoxy }}$ intermediate, showing $\mathrm{v}_{\mathrm{Fe}-\mathrm{His}}$ at 224 and 223 $\mathrm{cm}^{-1}$ (Fig. 6), values similar to those seen in deoxy-myoglobin (Mb), which has no quaternary constraints.

The postulated clamshell rotation can be seen by comparing high-resolution crystal structures of $\mathrm{MbCO}$ and deoxyMb, and has been successfully modeled in Mb with DFT/MM calculations(52). Importantly, it has also been observed in crystal structures of $\mathrm{Hb}$ from Antarctic fish which have been trapped in an intermediate conformation along the allosteric coordinate because of selective oxidation of $\beta$ subunits $(53,54)$. The clamshell rotation brings the distal $\mathrm{E}$ helix toward the heme, impelling the photodissociated $\mathrm{CO}$ to recombine geminately $(40 \%)$ or else to exit the distal pocket. The rate of geminate recombination is essentially the same as that of $R_{\text {deoxy }}$ formation. The $R_{\text {deoxy }}$ spectrum disappears in $0.75 \mu$ s signaling the reformation of the interhelical $\mathrm{H}$-bonds (intermediate $\mathrm{R}_{\mathrm{S}}$ )(18). This is suggested to result from subsequent motions of the $\mathrm{H}$ and $\mathrm{A}$ helices whose $\mathrm{C}$ and $\mathrm{N}$ termini form salt-bridges in the $\mathrm{T}$ state. These motions are viewed as a conformational search phase, resulting in the beginning of inter-dimer rotation and formation of the 'hinge' contact between the FG-corner of the $a_{p}$ chain and the C-helix of the $\beta_{2}$ chain, at $2.9 \mu$ s (intermediate $R_{T}$ )(18). The $R_{T}$ UVRR difference spectra reveal the resulting $\mathrm{H}$-bond between Trpß35 and Aspa94 at the rotation hinge. Finally, the 'switch' is thrown at $20 \mu$ s (intermediate $T^{\prime}$ '), as shown in the UVRR spectrum by a signal characteristic of the resulting $\mathrm{H}$-bond between Tyra42 on the C-helix of the $\mathrm{a}_{\mathrm{p}}$ chain and Asp 399 on the FG-corner of the $\beta_{2}$ chain. This completes the transition to the $T$ quaternary structure. However, because of the geminate recombination, the $\mathrm{Hb}$ tetramer retains 1-2 $\mathrm{CO}$ molecules on average, and the intermediate is labeled $\mathrm{T}^{\prime}$.

The heme RR spectra (Fig. 6 and and7)7) show divergent behavior for $a$ and $\beta$ chains following $R_{\text {deoxy }} V_{\mathrm{Fe} \text {-His }}$ between $R_{\text {deoxy, }}, R_{S}$ and $R_{T}$, but then a sharp drop in $T^{\prime}$. In contrast, the $\beta$ chain $v_{\mathrm{Fe}-\mathrm{His}}$ decreases gradually at each step, and is higher in $T^{\prime}$ than is the a

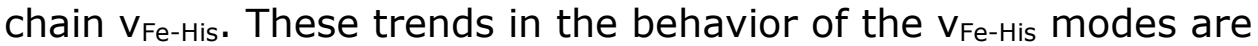
supported by the inverse behavior of the $\mathrm{v}_{4}$ modes seen in Figure 7 (discussed further below). For both chains the $T^{\prime}$ frequencies of the $\mathrm{V}_{\mathrm{Fe}-\mathrm{His}}$ band remain higher than those seen in deoxyHb (see Fig. 2 and and6).6). We conclude that the presence of the CO ligands in the $T^{\prime}$ intermediate perturb the $\mathrm{Hb}$ structure, even though the UVRR signals indicate the formation of T quaternary contacts. Quantification of the UVRR signals is problematic because of the issue of ligand distribution among the $\mathrm{Hb}$ molecules in the sample, and the uncertain relationship of ligand occupancy to quaternary state $(55,56)$. It is known, however,

Journal of Biological Inorganic Chemistry, Vol. 14, No. 5 (June 2009): pg. 741-750. DOI. This article is @ Springer and permission has been granted for this version to appear in e-Publications@Marquette. Springer does not grant permission for this article to be further copied/distributed or hosted elsewhere without the express permission from Springer. 
that structural perturbations in deoxyHb (induced by site-mutation or chemical modification) which weaken the UVRR difference signals, also shift the $\mathrm{V}_{\mathrm{Fe} \text {-His }}$ band to higher frequencies $(13,51,57,58)$.

Nevertheless, the sharp drop in the a chain $\mathrm{v}_{\mathrm{Fe}-\mathrm{His}}$ when the quaternary 'switch' is thrown at $20 \mu$ s supports the idea that the FeHis perturbation reflects molecular tension. Gibson showed long ago that $20 \mu s$ characterizes the transition between fast- and slowrecombining forms of hemoglobin (59). These forms were associated with the $\mathrm{R}$ and $\mathrm{T}$ states. This was why the penultimate $2.9 \mu \mathrm{s}$ intermediate was labeled $\mathrm{R}_{\mathrm{T}}$ (18), even though the formation of the hinge contact signals a quaternary motion; a recent time-resolved wide angle $x$-ray scattering study confirms a $3 \mu$ s time constant for quaternary motion (60). Perutz initially advanced the notion that protein-induced strain on the Fe-His bond could hinder the approach of the Fe to the heme plane, thereby inhibiting ligation(4). The temporal association of the $\mathrm{v}_{\mathrm{Fe}-\mathrm{His}}$ lowering with the lowering of ligation rate provides direct support for this mechanism.

Perutz also recognized that a different mechanism was required for the $\beta$ chains, and proposed steric hindrance to ligand entry, since deoxyHb crystal structures showed the distal pocket to be more crowded for the $\beta$ than the a chains(4). Subsequent measurements, especially those of Unzai et al $(61,62)$ with $\mathrm{Cr} / \mathrm{Fe}$ and $\mathrm{Zn} / \mathrm{Fe}$ hybrid $\mathrm{Hb}^{\prime} \mathrm{s}$, in which the $\mathrm{R}$ and $\mathrm{T}$ states are stabilized by the $\mathrm{Cr}$ (III) and $\mathrm{Zn}$ (II) ions, have shown little difference between $a$ and $\beta$ chain binding rates and affinities. Consistent with Perutz' proposal, DFT/MM calculations indicate similar R-T energy differences between the two chains, but with quite different apportioning of the energy to different structural elements in the heme pocket (52). Thus nature appears to have evolved similar energetic responses to allostery in the two chains, a requirement for cooperative binding, by distinctly different mechanisms.

We note that the $\mathrm{v}_{4}$ frequency shows a slight but distinctive evolution (Figure 7), as was also seen in the ${ }^{15} \mathrm{~N}$-heme isotopomer hybrid study [24]. Rousseau et al. (10) have noted a negative correlation between $\mathrm{v}_{\mathrm{Fe}} \mathrm{His}$ and $\mathrm{v}_{4}$ for a variety of $\mathrm{Hb}$ constructs. The present results allow us to test this correlation in the context of native $\mathrm{Hb}$. Figure 9 confirms the correlation for the $\mathrm{Hb}$ kinetic intermediates. It also reveals a distinctively greater slope for the a than the $\beta$ chains. The $v_{4}$ mode is responsive to electron density in the porphyrin ring (the upshift seen for $\mathrm{HbCO}$ reflects electron withdrawal by the $\mathrm{CO}$ ligand), which is modulated by alterations in the donor strength of the

Journal of Biological Inorganic Chemistry, Vol. 14, No. 5 (June 2009): pg. 741-750. DOI. This article is @ Springer and permission has been granted for this version to appear in e-Publications@Marquette. Springer does not grant permission for this article to be further copied/distributed or hosted elsewhere without the express permission from Springer. 
Fe-His bond. The higher slope is another manifestation of the greater constraint on this bond in the a than the $\beta$ chains.

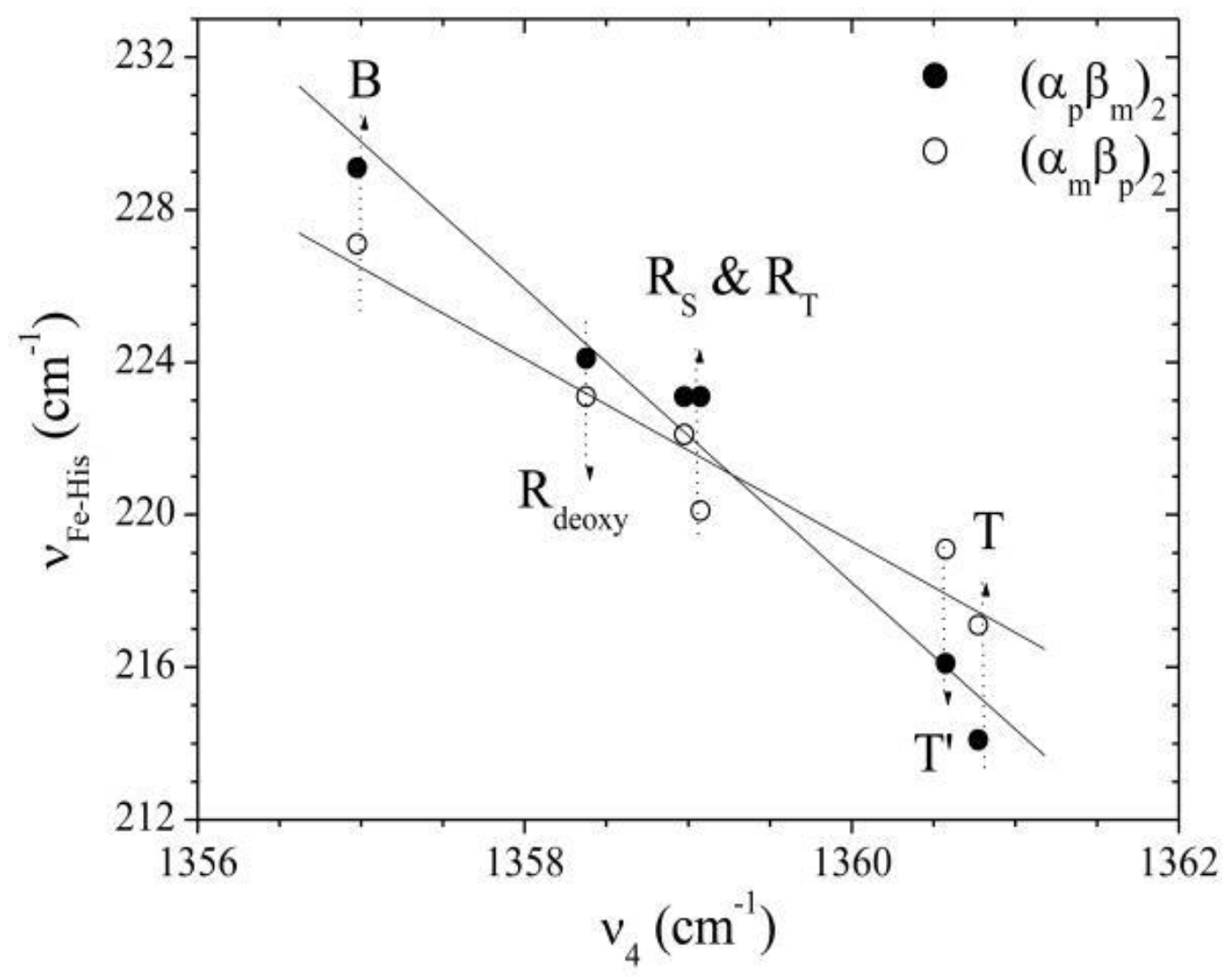

Figure 9 The $\mathrm{v}_{\mathrm{Fe}-\mathrm{His}} / \mathrm{v}_{4}$ correlation for the kinetic intermediates and for the deoxy $\mathrm{Hb}(\mathrm{T})$

\section{Conclusions}

Chain-selective substitution of meso-heme into $\mathrm{Hb}$ coupled with time-resolved pump-probe RR spectroscopy has revealed identical geminate $\mathrm{CO}$ recombination yields for $\mathrm{a}$ and $\beta$ chains, confirming the results obtained by selective $15-\mathrm{N}$ proto-heme substitution. In addition, the meso/proto hybrids have permitted chain selective monitoring of the Fe-His stretching vibration as it evolves through successive intermediates along the R-T allosteric coordinate. Immediately after $\mathrm{CO}$ photolysis, the Fe-His frequency is elevated in both chains, reflecting compression of the $\mathrm{Fe}-\mathrm{His}$ bond as the $\mathrm{Fe}$ is driven out of the heme plane. It relaxes with a time constant of 0.07 $\mu s$, reflecting relief of the bond compression as the His residue moves away from the heme during the clamshell rotation of the $E$ and $F$ helices. For the a chains, the Fe-His frequency then remains 
unperturbed during subsequent tertiary and quaternary intermediates, until the quaternary 'switch' is thrown, at $20 \mu \mathrm{s}$. The drop in a chain Fe-His frequency at this stage, coincident with a diminished $\mathrm{CO}$ rebinding rate, demonstrates that the 'switch' inhibits ligand binding by constraining the His ligand in the a chains. For the $\beta$ chains, the FeHis frequency is lowered slightly and gradually throughout the allosteric coordinate, ending at a higher value than in the a chains. This behavior indicates a different mechanism of ligand binding inhibition in the $\beta$ chains, consistent with computational results(52), and with the observation of distal crowding in the $\beta$ chain binding pocket.

\section{Acknowledgments}

This work was supported by NIH Grant GM12526 (to TGS) and DK35153 [to JRK]. We thank Princeton Instruments (Trenton, NJ) for loaning the PI/MAX detector used for this study.

\section{References}

1. Perutz MF. Nature. $1970 ; 228: 726-734$.

2. Baldwin J, Chothia C. J Mol Biol. 1979;129:175-220.

3. Monod J, Wyman J, Changeux JP. J Mol Biol. 1965;12:88-118.

4. Perutz MF. Mechanisms of Cooperativity and Allosteric Regulation in Proteins. Cambridge University Press; Cambridge: 1990.

5. Friedman JM, Scott TW, Stepnoski RA, Ikedasaito M, Yonetani T. J Biol Chem. 1983;258:564-572.

6. Kaminaka S, Ogura T, Kitagishi K, Yonetani T, Kitagawa T. J Am Chem Soc. $1989 ; 111: 3787-3794$

7. Kitagawa T, Nagai K, Tsubaki M. FEBS Lett. 1979;104:376-378.

8. Nagai K, Kitagawa T. Proc Nat Acad Sci USA - Biol Sci. 1980;77:20332037.

9. Ondrias MR, Rousseau DL, Kitagawa $T$, Ikedasaito $M$, Inubushi $T$, Yonetani T. J Biol Chem. 1982;257:8766-8770.

10. Ondrias MR, Rousseau DL, Shelnutt JA, Simon SR. Biochemistry. $1982 ; 21: 3428-3437$.

11. Friedman JM, Rousseau DL, Ondrias MR. Annu Rev Phys Chem. $1982 ; 33: 471-491$.

Journal of Biological Inorganic Chemistry, Vol. 14, No. 5 (June 2009): pg. 741-750. DOI. This article is @ Springer and permission has been granted for this version to appear in e-Publications@Marquette. Springer does not grant permission for this article to be further copied/distributed or hosted elsewhere without the express permission from Springer. 
NOT THE PUBLISHED VERSION; this is the author's final, peer-reviewed manuscript. The published version may be accessed by following the link in the citation at the bottom of the page.

12. Friedman JM, Rousseau DL, Ondrias MR, Stepnoski RA. Science. $1982 ; 218: 1244-1246$.

13. Jayaraman V, Rodgers KR, Mukerji I, Spiro TG. Science. 1995;269:18431848.

14. Jayaraman V, Spiro TG. Biospectrosc. 1996;2:311-316.

15. Scott TW, Friedman JM. J Am Chem Soc. 1984;106:5677-5687.

16. Jeyarajah S, Kincaid JR. Biochemistry. 1990;29:5087-5094.

17. Podstawka E, Proniewicz LM. J Inorg Biochem. 2004;98:1502-1512.

18. Balakrishnan G, Case MA, Pevsner A, Zhao XJ, Tengroth C, McLendon GL, Spiro TG. J Mol Biol. 2004;340:843-856.

19. Rodgers KR, Su C, Subramaniam S, Spiro TG. J Am Chem Soc. $1992 ; 114: 3697-3709$

20. Antonini E, Brunori M. Hemoglobin and Myoglobin and their Reactions with Ligands. Elsevier; New York: 1971.

21. Riggs A, Eraldo Antonini LR-BaEC. Methods Enzymol. Academic Press; 1981. pp. 5-29.

22. Ascoli F, Rossi Fanelli MR, Antonini E, Eraldo Antonini LR-BaEC. Methods Enzymol. Academic Press; 1981. pp. 72-87.

23. Yip YK, Waks M, Beychok S. J Biol Chem. 1972;247:7237-7244.

24. Bucci E, Eraldo Antonini LR-BaEC. Methods Enzymol. Academic Press; 1981. pp. 97-106.

25. Geraci G, Parkhurs Lj, Gibson QH. J Biol Chem. 1969;244:4664-4667.

26. Yip YK, Waks M, Beychok S. Proc Nat Acad Sci USA. 1977;74:64-68.

27. Ikeda-Saito M, Inubushi T, Yonetani T, Eraldo Antonini LR-BaEC. Methods Enzymol. Academic Press; 1981. pp. 113-121.

28. Makino N, Sugita Y. J Biol Chem. 1978;253:1174-1178.

29. Yamamoto H, Yonetani T. J Biol Chem. 1974;249:7964-7968.

30. Zhao XJ, Chen RP, Tengroth C, Spiro TG. Appl Spectrosc. 1999;53:12001205.

31. Zhao XJ, Tengroth C, Chen RP, Simpson WR, Spiro TG. Journal of Raman Spectroscopy. 1999;30:773-776.

32. Olson JS. Proc Nat Acad Sci USA. 1976;73:1140-1144.

33. Sugita Y. J Biol Chem. 1975;250:1251-1256.

Journal of Biological Inorganic Chemistry, Vol. 14, No. 5 (June 2009): pg. 741-750. DOI. This article is (C Springer and permission has been granted for this version to appear in e-Publications@Marquette. Springer does not grant permission for this article to be further copied/distributed or hosted elsewhere without the express permission from Springer. 
34. Balakrishnan G, Zhao XJ, Podstawska E, Proniewicz LM, Kincaid JR, Spiro TG. Biochemistry. 2008. Submitted.

35. Spiro TG, Burke JM. J Am Chem Soc. 1976;98:5482-5489.

36. Choi S, Spiro TG, Langry KC, Smith KM. J Am Chem Soc. $1982 ; 104: 4337-4344$.

37. Choi S, Spiro TG, Langry KC, Smith KM, Budd DL, Lamar GN. J Am Chem Soc. $1982 ; 104: 4345-4351$.

38. Hu SZ, Smith KM, Spiro TG. J Am Chem Soc. 1996;118:12638-12646.

39. Kaminaka S, Zhou YX, Tsuneshige A, Yonetani T, Kitagawa T. J Am Chem Soc. $1994 ; 116: 1683-1689$.

40. Ishimori K, Morishima I. Biochemistry. 1986;25:4892-4898.

41. Seybert DW, Moffat K. J Mol Biol. 1977;113:419-430.

42. Seybert DW, Moffat K, Gibson QH. Biochem Biophys Res Commun. $1975 ; 63: 43-49$.

43. Seybert DW, Moffat K, Gibson QH. J Biol Chem. 1976;251:45-52.

44. Yonetani T, Tsuneshige A, Zhou YX, Chen XS. J Biol Chem. $1998 ; 273: 20323-20333$.

45. Fujii M, Hori $H$, Miyazaki G, Morimoto $H$, Yonetani T. J Biol Chem. 1993;268:15386-15393.

46. Shelnutt JA, Alston K, Ho JY, Yu NT, Yamamoto T, Rifkind JM. Biochemistry. 1986;25:620-627.

47. Sudhakar K, Laberge M, Tsuneshige A, Vanderkooi JM. Biochemistry. $1998 ; 37: 7177-7184$.

48. Mukerji I, Spiro TG. Biochemistry. 1994;33:13132-13139.

49. Balakrishnan G, Tsai CH, Wu Q, Case MA, Pevsner A, McLendon GL, Ho C, Spiro TG. J Mol Biol. 2004;340:857-868.

50. Wang DJ, Zhao XJ, Shen TJ, Ho C, Spiro TG. J Am Chem Soc. 1999;121:11197-11203.

51. Kneipp J, Balakrishnan G, Chen RP, Shen TJ, Sahu SC, Ho NT, Giovannelli JL, Simplaceanu V, Ho C, Spiro TG. J Mol Biol. 2006;356:335-353.

52. Guallar V, Jarzecki AA, Friesner RA, Spiro TG. J Am Chem Soc. $2006 ; 128: 5427-5435$.

53. Riccio A, Vitagliano L, di Prisco G, Zagari A, Mazzarella L. Proc Nat Acad Sci USA. 2002;99:9801-9806.

Journal of Biological Inorganic Chemistry, Vol. 14, No. 5 (June 2009): pg. 741-750. DOI. This article is @ Springer and permission has been granted for this version to appear in e-Publications@Marquette. Springer does not grant permission for this article to be further copied/distributed or hosted elsewhere without the express permission from Springer. 
NOT THE PUBLISHED VERSION; this is the author's final, peer-reviewed manuscript. The published version may be accessed by following the link in the citation at the bottom of the page.

54. Vitagliano L, Vergara A, Bonomi G, Merlino A, Verde C, di Prisco G, Howes BD, Smulevich G, Mazzarella L. J Am Chem Soc. 2008;130:1052710535.

55. Ackers GK, Holt JM, Huang YW, Grinkova Y, Klinger AL, Denisov I. Proteins-Structure Function and Genetics. 2000. pp. 23-43.

56. Ciaccio C, Coletta A, De Saneti G, Marini S, Coletta M. Iubmb Life. 2008;60:112-123.

57. Ishimori K, Hashimoto M, Imai K, Fushitani K, Miyazaki G, Morimoto $H$, Wada Y, Morishima I. Biochemistry. 1994;33:2546-2553.

58. Juszczak L, Samuni U, Friedman J. Journal of Raman Spectroscopy. $2005 ; 36: 350-358$.

59. Sawicki CA, Gibson QH. J Biol Chem. 1976;251:1533-1542.

60. Cammarata M, Levantino M, Schotte F, Anfinrud PA, Ewald F, Choi J, Cupane A, Wulff M, Ihee H. Nat Methods. 2008;5:881-886.

61. Unzai S, Eich R, Shibayama N, Olson JS, Morimoto H. J Biol Chem. 1998;273:23150-23159.

62. Unzai S, Hori H, Miyazaki G, Shibayama N, Morimoto H. J Biol Chem. $1996 ; 271: 12451-12456$.

\section{About the Authors}

Thomas G. Spiro : spiro@chemistry.washington.edu

James R. Kincaid : james.kincaid@marquette.edu

Journal of Biological Inorganic Chemistry, Vol. 14, No. 5 (June 2009): pg. 741-750. DOI. This article is (C) Springer and permission has been granted for this version to appear in e-Publications@Marquette. Springer does not grant permission for this article to be further copied/distributed or hosted elsewhere without the express permission from Springer. 